\title{
Society of soil
}

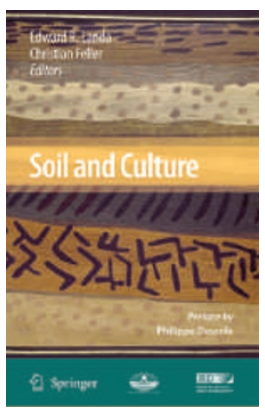

Soil and Culture

edited by

Edward R. Landa

and Christian Feller

SPRINGER: 2010.

488 PP. $\$ 199$

t was November 1996, and a group of us at the Soil Science Society of America conference were watching the election results. A map of red versus blue states appeared on the television screen and someone blurted out, "but that's a soils map!" Indeed it was: mollisols and ultisols were red, spodosols and inceptisols were blue. We all erupted in laughter, both at the amusing observation and our own obsession. As I thought about that incident, however, I realized that it wasn't an accident that the political and soils maps matched up. The soils map drove the political map; fertile soils select for a rural farming economy with a socially conservative culture, and nutrient-poor soils encourage an urban or industrial economy with a more liberal society.

Soils define culture. Throughout history soil has defined human societies perhaps more strongly than any other single environmental variable. Its fertility defines our food, our population and our economy. Its colours define our art. Its organisms may define our health. Yet, the importance of soils in regulating human society is frequently overlooked. Soil and Culture, a collection of essays by a variety of authors, fills this gap by illustrating the full suite of ways in which soils affect human society. Many of the chapters are gems, either compiling fascinating information or providing deep insight.

Soil and art is one of the book's main themes. A chapter on colour and paints reveals how artists have relied on soil pigments. The colours of the Renaissance masters were dominated by iron-oxiderich yellows, celadonite-rich greens and kaolinite-derived whites. The whole colour spectrum of painting changed with the impressionists and the development of synthetic chemical colours. Another chapter uses landscape paintings to analyse historical land use and abuse in Southeast Asia. Such is the accuracy of the paintings depicting the deforested slopes and eroded landscapes of Guangdong Province that geomorphologists now use these paintings to determine how the sites have changed over time. In other chapters the reader learns that the work of artists such as Gaugin is dominated by the colours in soils, and that the literature of geologiststurned-poets in the Soviet Union was based around soils. This movement of soil-inspired poetry flowered in the early 1950's, and reflected the politics and culture of the time. But it became politicized and faded away after the Hungarian Revolution in 1956.

\section{Eating soil until it clogged the digestive system was even a method of suicide; one so common during slavery that owners put iron masks on some slaves to keep them from killing themselves.}

My favourite chapter by far is Lina Kriner's 'Creating Fiber Art with Soil and Rust', which describes her quest to use local soils as dying agents in her textile art. It was deeply personal, evocative and beautifully written. How often is it that "the 'Ah-Ha!' moment all artists dream of" comes from stomping a piece of cloth into the dirt and marvelling at the rich colour that results? More than any other chapter in the book, this one illustrated a real love of soil and the environment it embodies. I also love her art. Her chapter not only analyses culture, it is culture.

The influence of soil on food is also explored. Topics range from the effect of soils on the terroir of wines to geophagy the practice of eating soil - and whether it has any nutritional value or simply acts as a solid mass to make starving people feel full (although I was left wondering how much of the organic matter in soil might actually be digestible). Eating soil until it clogged the digestive system was even a method of suicide; one so common during slavery that owners put iron masks on some slaves to keep them from killing themselves.
Another section discusses how different cultures view soils. Indigenous Caribbean people believe that rocks grow from the soil - a feeling that many of us who garden may have had, but which is certainly at odds with the scientific perspective of soil weathering from rock. The Tanala people of Madagascar use slash-and-burn agriculture on rich midslope soils that are resistant to erosion, but avoid farming more vulnerable ridgetop soils and small gulley-prone valleys. This sensitivity to landscape and soil has enabled the Tanala people to avoid the extensive land degradation common in the rest of Madagascar.

But soil has its dark side, too. Soil-borne diseases, such as hookworm and Giardia, inflict many. The larvae of the TseTse flies, which carry sleeping sickness and inhabit large parts of Africa, live in organic-matterrich black soils. And between epidemics, Yersinia pestis - thought to be responsible for the 'black death' in medieval Europe lives underground.

My second favorite chapter, 'Yellow Sands and Penguins: The Soil of the 'Great Escape", discusses the challenges faced by allied prisoners trying to escape a prisoner of war camp during the Second World War - as depicted in the famous film The Great Escape. The camp was built on a tunnel-digger's nightmare: a thin grey surface soil overlying bright yellow sand. To hide tons of digging spoils, the prisoners would waddle about with tubes of soil stashed up their trouser legs, letting it slowly dribble out while they scuffled it into the topsoil with their feet. This fascinating story, blending soil science and history, is only marred by its gruesome end - 50 escapees were executed.

The drive for sustainability calls for the reintegration of human society and the environment. Soil and Culture gives a face to what that means, and shows how a blending of the natural sciences, social sciences and humanities can provide deep insights into humanity's relationship with nature. It is a lovely book.

\section{REVIEWED BY JOSHUA SCHIMEL} Joshua Schimel is in the Department of Ecology, Evolution and Marine Biology, University of California Santa Barbara, Santa Barbara, California 93106, USA.

e-mail:Schimel@lifesci.ucsb.edu 